\title{
OBITUARY
}

\section{WILFRED GEORGE LAMBERT, MA (Cantab), F.B.A. (1926-2011)}

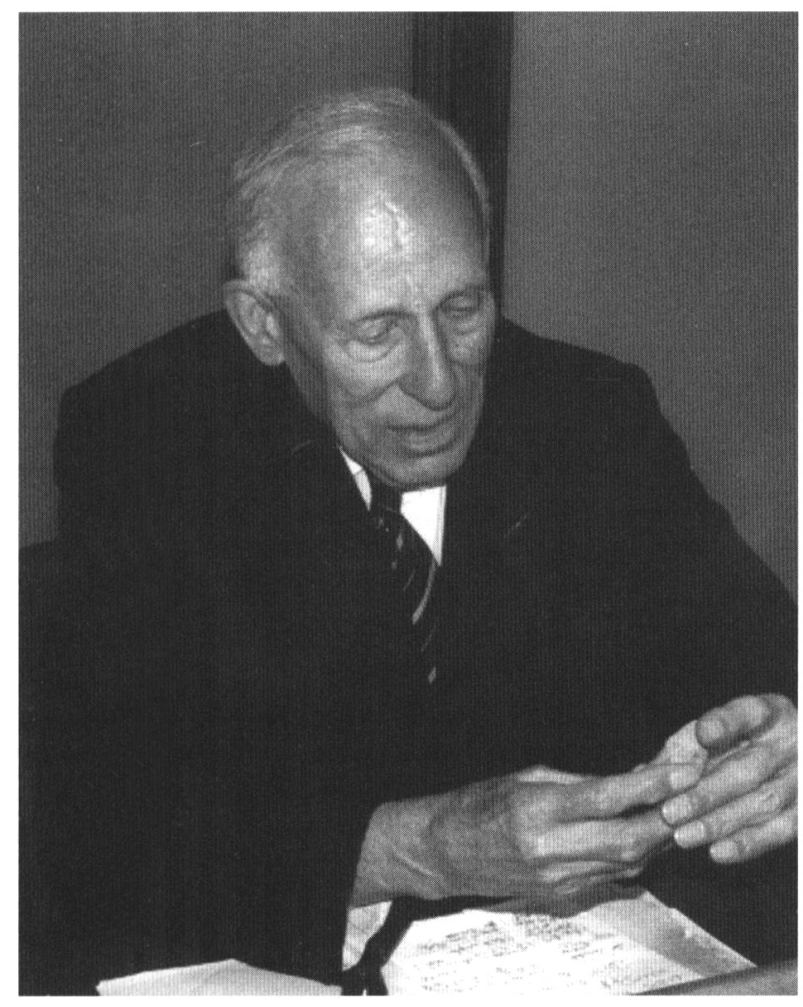

The death of Prof. Wilfred George Lambert on 9 November 2011 signalled the loss of one of the last remaining giants of post-War Assyriology, whose ground-breaking research permanently altered the course of cuneiform studies in the UK and fundamentally influenced Assyriology and biblical studies in Europe and America. This legacy of scholarly achievement was both hard-earned and beset by imposing challenges which a less-determined personality would hardly have been able to overcome.

W. G. Lambert was essentially an autodidact in Assyriology, his main teacher of Akkadian at Cambridge being C.P.T. Winckworth, who published only a single article; Lambert nevertheless remembered him with fondness. Lambert's Cambridge career fell short of distinction because of opposition from D. Winton-Thomas, which meant he could not carry on with research. Instead, he became a Classics and music master at Westminster Under School in London and approached Sidney Smith, Keeper in the British Museum, about working on cuneiform tablets. Abraham Sachs also helped him a great deal with cuneiform at this period. Smith suggested to the young Lambert that he edit the tablets later published in Babylonian Wisdom Literature (1960). It was this work which gave him immediate international renown, and in fact no other subsequent book could match its impact within Assyriology and related disciplines. In the years to come he would be elected Fellow of the British Academy (1971) and made Honorary Professor of the Collège de France (1978).

In 1956, Lambert was appointed to the University of Toronto, and after a few years he was called to the Johns Hopkins University as successor to W. F. Albright, the doyen of American Semitists. His focus on Mesopotamia ran counter to Albright's approach, which had the Bible as the central axis of all Near Eastern languages. During this period, American Assyriology was in turmoil, with the all-powerful third floor of the University of Chicago's Oriental Institute wracked by arguments regarding the quality of the first published volumes of the Assyrian Dictionary. Lambert was called in as consultant to review and correct manuscripts, which he did until the end of the dictionary 
project. He recalled bringing his extensive corrections to an entry to the editor, A. L. Oppenheim, complaining that the article must have been drafted by a young student; it was clear from the conversation, however, that it had been written by Oppenheim himself.

Lambert gave Johns Hopkins little notice when invited back to his native Birmingham in 1971. He immediately established his routine of working in the British Museum every Thursday, which endured for the next 40 years. He successfully campaigned for more liberal Museum policies of access to tablets, and he instituted his own Assyriology curriculum in which his students were required to read texts of every period; Birmingham was the only UK university where students read both Akkadian and Sumerian. He demanded that his postgraduate students read texts every week throughout the period of writing their dissertations. Standards were high. He demanded accuracy and precision in both grammatical reading and translation of a text and discussion of its contents, while grammatical errors ('Ah, first year Akkadian') were equivalent to mortal sin. Disciples soon learned not to expect praise; the best one could hope for was the absence of too much critical comment. When one gave Lambert a manuscript to read (on the train), on the following Thursday one was invited to sit in the 'hot seat' in the British Museum Students' Room for a thorough verbal caning, fully audible to all other colleagues present. Nevertheless, this was preferable to reading Lambert's didactic tone in a review of one's book. In 2002, Lambert received a Festschrift with the title Wisdom, Gods and Literature, reflecting his own initials and interests. It was later reported that on the train back to Birmingham, he opened the volume, took out his pen and began noting corrections.

Lambert's extensive knowledge of the Kuyunjik collection immersed him within literary genres, but the main focus was religion. Although Lambert rarely referred to the Bible in his teaching or even research, the underlying agenda was nearly always related to religious themes, e.g. wisdom literature, creation stories (his publication of Atrahasis), god lists, incantations appeasing an angry god, oracle questions, and even the Gilgamesh Epic. While Lambert had no time for Derrida, Freud, or LeviStrauss, his work always bore some theoretical relevance to the Old Testament, even if not specifically stated. This may be why he always attended meetings of the Society for Old Testament Studies, to which he was even elected as President in 1984, serving as the authoritative voice of Mesopotamia whenever biblical parallels were discussed; no one has succeeded Lambert in this role.

Lambert also had a major interest in glyptic, being one of the very few scholars who read difficult inscriptions on cylinder seals, including those with alphabetic inscriptions. He pursued god names and divine roles into all genres of administrative as well as literary texts, with related iconography, and he had a keen appreciation for esoteric texts and learned ancient commentaries. Like all serious scholars, he could be distracted from his major projects, as happened during the explosion of interest in Ebla texts. The full extent of Lambert's scholarly legacy, however, still remains to be evaluated, since his edition of Mesopotamian creation stories was completed shortly before his death, and his Nachlass contains numerous unpublished copies and editions of crucially important tablets which await publication.

A sometimes controversial aspect of Lambert's career was the ubiquitous appearance of his letters confirming the authenticity of various artifacts and tablets. He had always habitually visited private collections and dealers in order to transliterate tablets and seal inscriptions (which he never published), long before such holdings were attacked by archaeologists. Lambert never deviated from this practice, despite criticism, since he was motivated by a desire to know about every cuneiform tablet in circulation, and to record their contents. He recognised, for instance, the significance of a cache of still unpublished tablets from the city of Yehud in Babylonia, which contained Hebrew names, and he was the first to note the importance of many tablets housed in the Schøyen collection, now being published by his student Andrew George.

He was a lifelong vegetarian and a pacificist, working as a gardener during his period of national service. These beliefs were rooted in his Christadelphian religious upbringing, which he never openly discussed with colleagues; they reveal a deep non-conformist commitment. Lambert was known for certain eccentricities, such as the fact that he had no refrigerator at home, maintaining that in America no one ate fresh food. He had no car, no television, and no need for a telephone at home, since he stayed in his office until 11 most evenings. It was not uncommon to receive a telephone call 
from Lambert at this late hour, with the greeting, 'Lambert speaking'. First names were an issue; none of his disciples ever called him 'Wilfred', and it took years before he began calling his own students and younger colleagues by their first names. Even in his writing, he always referred to himself as the 'present writer' or 'present reviewer'. When Lambert learned about my becoming a father, he simply looked up from his newspaper and said, 'Ah, increasing your liabilities!' He never asked whether it was a boy or girl.

Lambert was the classic image of a professor whose corrective voice still chimes in the ears of his former students as they confront new texts, and his legacy will endure for generations of students to come.

M. J. Geller

[Editorial note: Although not fond of committee work, Prof. Lambert served on the Council of the British School of Archaeology in Iraq from 1969 to 1996.] 